\title{
A Straightforward Synthesis of Panaxytriol:
}

\section{An Active Component of Red Ginseng}

\author{
Heedong Yun ${ }^{\dagger, *}$ and Samuel J. Danishefsky ${ }^{\dagger,+, *}$ \\ Department of Chemistry, Columbia University, Havemeyer Hall, 3000 Broadway, New York, \\ N.Y. 10027 (USA) and Laboratory for Bioorganic Chemistry, Sloan-Kettering Institute for \\ Cancer Research, 1275 York Ave., New York, N.Y. 10021 (USA) \\ s-danishefsky@ski.mskcc.org
}

Supporting Information

\section{General Procedures}

All commercial materials were used without further purification unless otherwise noted. THF, diethyl ether and dichloromethane used as reaction solvents were obtained from a dry system (alumina) and used without further drying. All reactions were performed under a positive pressure of argon atmosphere in flame dried vessel. ${ }^{1} \mathrm{H}$ NMR spectra were obtained on 300 and $400 \mathrm{MHz}$ instruments and are reported in parts per million (d) using residual non deuterated solvent as internal reference. ${ }^{13} \mathrm{C}$ NMR spectra were recorded on $75 \mathrm{MHz}$ and $125 \mathrm{MHz}$ instruments and reported in parts per million (d) using residual non deuterated solvent as internal reference. IR spectra were taken as a thin film on a FT-IR Spectrometer. Optical rotations were 
recorded on a polarometer using a $1 \mathrm{dm}$ cell at the reported temperatures and concentrations. High resolution mass spectra were recorded on mass spectrometer. Liquid column chromatography was performed using forced flow of a mixture of solvents on silica gel 60 (40$63 \mathrm{~mm})$.

\section{Compound (3)}

(R)-Me-CBS reagent $(2.14 \mathrm{~mL}, 2.14 \mathrm{mmol}, 1.0 \mathrm{M}$ in toluene solution) was transferred into a freshly flame dried flask and toluene was completely removed in vacuo for 1 day. After CBS reagent was diluted with THF, the resulting solution was transferred to a flask of compound (2) $(163 \mathrm{mg}, 1.07 \mathrm{mmol})$ at r.t. and the reaction temperature cooled down to $-30^{\circ} \mathrm{C}$. At $-30^{\circ} \mathrm{C}$, $\mathrm{BH}_{3} \bullet \mathrm{Me}_{2} \mathrm{~S}(\mathrm{BMS})(0.589 \mathrm{~mL}, 1.18 \mathrm{mmol})$ was slowly added over $10 \mathrm{~min}$. After addition of BMS, TLC analyses indicated complete reaction. Methanol was slowly added and reaction mixture was slowly warmed up to r.t.. Reaction mixture was diluted with diethyl ether, washed with 2:1(v:v)=NaOH:sat. $\mathrm{NaHCO}_{3}$ solution until aq. phase was clear, and then washed with brine. After being dried over $\mathrm{MgSO}_{4}$, solvent was removed. The resulting organic phase was diluted with diethyl ether and to this was added $0.5 \mathrm{M} \mathrm{HCl}$ in methanol solution $(4.5 \mathrm{~mL}, 2.14 \mathrm{mmol})$. Precipitation was removed by filtration and solvent was removed. The crude product was purified by silica gel column chromatography (hexane:ether=5:1) to give compound $(\mathbf{3})(0.123 \mathrm{~g}$,

$75 \%)$ as a colorless oil : $\mathrm{R}_{f} 0.4$ (hexane:dichloromethane $\left.=2: 1\right) ;[\alpha]_{\mathrm{D}}{ }^{20.0}-24.1\left(c=1, \mathrm{CHCl}_{3}\right) ;{ }^{1} \mathrm{H}$ NMR (400MHz, $\left.\mathrm{CDCl}_{3}\right) \delta 5.95(\mathrm{ddd}, 1 \mathrm{H}, J=17.0,10.1,5.29), 5.46(\mathrm{~d}, 1 \mathrm{H}, J=17.0), 5.21(\mathrm{~d}, 1 \mathrm{H}$, $J=10.1), 4.86(\mathrm{~d}, 1 \mathrm{H}, J=3.87), 2.17(\mathrm{br}, 1 \mathrm{H}), 0.16(\mathrm{~s}, 9 \mathrm{H}) ;{ }^{13} \mathrm{C} \mathrm{NMR}\left(125 \mathrm{MHz}, \mathrm{CDCl}_{3}\right) \delta 137.0$ 116.8, 104.9, 91.3, 63.9, 0.2 ; IR (neat) v 3368.7, 2961.3, 2927.0, 2855.3, 2174.4, 1250.9, $843.7 \mathrm{~cm}^{-1}$; HRMS (calcd. 154.28, found 154.0817 ) 
According to the Mosher's method, the corresponding Mosher ester was prepared using $(R)$ MTPA-Cl. The proton signals $(\delta 6.091,5.868)$ of the corresponding Mosher ester of $\mathbf{3}$ appeared at higher field than those $(\delta 6.119,5.958)$ of the other $(S)$-isomer.

\section{Compound (4)}

Compound (3) (204mg, 1.32mmol) was dissolved in acetone. NBS (353mg, 1.98mmol) and silver nitrate $(45 \mathrm{mg}, 0.26 \mathrm{mmol})$ were added to this solution. The reaction mixture was stirred at r.t. for 1 hour. The mixture was cooled to $0^{\circ} \mathrm{C}$, mixed with cold water and extracted with ether. The extract was washed with water and brine, dried over $\mathrm{MgSO}_{4}$, and concentrated under reduced pressure. The residue was purified by silica gel column chromatography (hexane:ether $=4: 1)$ to give compound (4) $(212 \mathrm{mg}, 100 \%)$ as a colorless oil : $\mathrm{R}_{f} 0.49$ (hexane:ether=2:1); $[\alpha]_{\mathrm{D}}{ }^{20.4}-31.61\left(c=1, \mathrm{CHCl}_{3}\right) ;{ }^{1} \mathrm{H}$ NMR $\left(400 \mathrm{MHz}, \mathrm{CDCl}_{3}\right) \delta 5.94(\mathrm{~m}, 1 \mathrm{H})$, $5,47(\mathrm{~d}, 1 \mathrm{H}, J=17.0), 5.24(\mathrm{~d}, 1 \mathrm{H}, J=10.1), 4.88(\mathrm{~d}, 1 \mathrm{H}, J=5.34), 2.44(\mathrm{br}, 1 \mathrm{H}) ;{ }^{13} \mathrm{C}$ NMR $\left(125 \mathrm{MHz}, \mathrm{CDCl}_{3}\right) \delta 136.7,117.4,79.3,64.3,47.2$; IR (neat) v 3361.2, 2918.7, 2852.9, $2356.6 \mathrm{~cm}^{-1}$; HRMS (calcd. 161.00, found 161.0334)

\section{Compound (6)}

To a DMF solution of compound $(\mathbf{5})(4.0 \mathrm{~mL}, 21.6 \mathrm{mmol})$ was added imidazole $(2.0 \mathrm{~g}$, $25.9 \mathrm{mmol})$ at r.t. and the resulting reaction mixture was cooled to $0^{\circ} \mathrm{C}$. Then $\mathrm{TBSCl}(4.0 \mathrm{~g}$, $25.9 \mathrm{mmol}$ ) was slowly added to the reaction mixture at $0^{\circ} \mathrm{C}$. Following warming r.t., the resulting mixture was stirred at r.t. for 6 hours. Water was added and the organic phase was extracted with ether, washed with brine, dried over $\mathrm{MgSO}_{4}$, and concentrated under reduced pressure. The residue was purified by silica gel column chromatography (hexane only to 
hexane:ethyl acetate $=10: 1)$ to give compound $(6)(5.78 \mathrm{~g}, 99 \%)$ as a colorless oil $: \mathrm{R}_{f} 0.35$ (hexane only) ; ${ }^{1} \mathrm{H}$ NMR $\left(400 \mathrm{MHz}, \mathrm{CDCl}_{3}\right) \delta 5.6(\mathrm{~m}, 1 \mathrm{H}), 5.5(\mathrm{~m}, 1 \mathrm{H}), 4.12(\mathrm{dd}, 2 \mathrm{H}, J=5.25$, 1.19), 2.00 (dd, $2 \mathrm{H}, J=13.5,6.57), 1.38-1.27(\mathrm{~m}, 10 \mathrm{H}), 0.91-0.86(\mathrm{~m}, 12 \mathrm{H}), 0.05(\mathrm{~s}, 6 \mathrm{H}) ;{ }^{13} \mathrm{C}$ NMR $\left(125 \mathrm{MHz}, \mathrm{CDCl}_{3}\right) \delta 131.7,129.4,64.6,32.8,32.4,29.9,29.8,26.6,23.3,19.0,14.7,-4.4$; IR (neat) v 2957.0, 2928.1, 2856.7, 1471.8, 1255.3, 1103.1, 836.7, 775.6cm ${ }^{-1}$; HRMS (calcd. 270.53, found 270.2403)

\section{Compound (7)}

A flask, equipped with a magnetic stirrer, was charged with tert-butyl alcohol:water=1:1 solution, and AD-mix- $\beta$ (42.8g) and $\mathrm{MeSO}_{2} \mathrm{NH}_{2}(2.91 \mathrm{~g}, 30.6 \mathrm{mmol})$. The mixture was stirred at r.t. until both phases were clear, and then cooled to $0^{\circ} \mathrm{C}$ and tert-butyl alcohol:water $=1: 1$ solution of compound $(\mathbf{6})(8.24 \mathrm{~g}, 30.5 \mathrm{mmol})$ was added. The heterogeneous slurry was stirred vigorously at $0^{\circ} \mathrm{C}$ for 1 day. The reaction was quenched at $0^{\circ} \mathrm{C}$ by addition of sodium sulfite $(45.7 \mathrm{~g})$ and then warmed to r.t. and stirred for 1 hour. The reaction mixture was extracted with dichloromethane, washed with $2 \mathrm{~N} \mathrm{KOH}$ and then dried over $\mathrm{MgSO}_{4}$ and concentrated under reduced pressure. The residue was purified by silica gel column chromatography (hexane:ethyl acetate $=5: 1)$ to give compound $(7)(9.56 \mathrm{~g}, 100 \%)$ as a yellow oil $: \mathrm{R}_{f} 0.35$ (hexane:ethyl acetate $=5: 1) ;[\alpha]_{\mathrm{D}}{ }^{19.9}+9.72\left(c=1, \mathrm{CHCl}_{3}\right) ;{ }^{1} \mathrm{H} \mathrm{NMR}\left(400 \mathrm{MHz}, \mathrm{CDCl}_{3}\right) \delta 3.76(\mathrm{~m}, 1 \mathrm{H}), 3.68(\mathrm{~m}$, 1H). $3.62(\mathrm{~m}, 1 \mathrm{H}), 3.46(\mathrm{~m}, 1 \mathrm{H}) .2 .57(\mathrm{br}, 1 \mathrm{H}), 1.52-1.25(\mathrm{~m}, 12 \mathrm{H}), 0.88(\mathrm{~m}, 12 \mathrm{H}), 0.07(\mathrm{~s}, 6 \mathrm{H})$; ${ }^{13} \mathrm{C}$ NMR $\left(125 \mathrm{MHz}, \mathrm{CDCl}_{3}\right) \delta 73.5,72.8,66.4,34.1,32.4,30.2,29.8,29.2,26.1,23.2,14.7,-4.7$ 
; IR (neat) v 3394.3, 2954.4, 2930.7, 2859.3, 1468.4, 1260.3, 1111.7, 838.8 $\mathrm{cm}^{-1}$; HRMS (calcd. 304.54, found 305.2540)

Following the Mosher's method, the corresponding bis-Mosher ester was prepared using $(R)$ MTPA-Cl. The proton signals $(\delta 5.355,5.282)$ of the corresponding bis-Mosher ester of 7 appeared at higher field than those $(\delta 5.430,5.291)$ of the other $(S, S)$-isomer.

\section{Compound (8)}

Compound (7) $(1.00 \mathrm{~g}, 3.28 \mathrm{mmol})$, 2,2-dimethoxypropane $(0.6 \mathrm{~mL}, 4.93 \mathrm{mmol})$ and $p$-TsOH (catalytic) in dichloromethane were stirred at r.t. for 1 hour. The reaction was neutralized with triethylamine, concentrated under reduced pressure. The crude product was used for a further step without additional purification. To a suspension of $\mathrm{Ph}_{3} \mathrm{PBr}_{2}$ in dichloromethane was added a solution of crude product in the previous reaction in dichloromethane at r.t., and the resulting mixture was stirred at r.t. for $30 \mathrm{~min}$. Subsequently, dichloromethane was added and the solution washed with water, dried over $\mathrm{MgSO}_{4}$ and concentrated under reduced pressure. The residue was purified by silica gel column chromatography (hexane:ethyl acetate=5:1) to give compound $(\mathbf{8})$ $(0.834 \mathrm{~g}, 90 \%)$ as a yellow oil. This material was used directly without further purification.

\section{Compound (9)}

Compound $(8)(0.834 \mathrm{~g}, 2.84 \mathrm{mmol})$ and $1 \mathrm{~N} \mathrm{HCl}$ in ethanol was stirred at r.t. for 3 days and neutralized with potassium carbonate $(0.4 \mathrm{~g})$. More potassium carbonate $(0.8 \mathrm{~g})$ was then added to the reaction mixture and the $\mathrm{pH}$ adjusted to around 8-9. The reaction mixture was vigorously stirred at r.t. overnight. Ethanol was removed under reduced pressure and the residue was extracted with ether, washed with water, dried over $\mathrm{MgSO}_{4}$ and concentrated under reduced 
pressure. The residue was purified by silica gel column chromatography (hexane:ethyl acetate $=10: 1$ to $7: 1)$ to give compound (9) $(0.354 \mathrm{~g}, 89 \%$ based on recovered starting material) as a yellow oil and starting material $(0.158 \mathrm{~g}): \mathrm{R}_{f} 0.6$ (hexane:ethyl acetate $\left.=1: 1\right) ;[\alpha]_{\mathrm{D}}{ }^{19.1}-3.38(c=1$, $\left.\mathrm{CHCl}_{3}\right) ;{ }^{1} \mathrm{H}$ NMR (400MHz, $\left.\mathrm{CDCl}_{3}\right) \delta 3.44(\mathrm{~m}, 1 \mathrm{H}), 2.94(\mathrm{~m}, 1 \mathrm{H}), 2.77(\mathrm{~d}, 1 \mathrm{H}, J=4.84), 2.67(\mathrm{~d}$, $1 \mathrm{H}, J=4.93), 2.45(\mathrm{br}, 1 \mathrm{H}), 1.62-1.26(\mathrm{~m}, 12 \mathrm{H}), 0.84(\mathrm{t}, 3 \mathrm{H}, J=6.72) ;{ }^{13} \mathrm{C}$ NMR $(125 \mathrm{MHz}$ $\left.\mathrm{CDCl}_{3}\right) \delta 72.1,55.9,45.5,34.6,32.1,29.9,29.5,25.6,22.9,14.4$; IR (neat) $v$ 3443.0, 2933.6, 2858.9, 2342.6, 1466.4, 1255.8, 923.0 $\mathrm{cm}^{-1}$; HRMS (calcd. 172.26, found 171.1388)

\section{Compound (10)}

To a solution of lithiumacetylide-ethylenediamine complex $(0.330 \mathrm{~g}, 3.58 \mathrm{mmol})$ in THF and HMPA $(0.2 \mathrm{ml})$, compound $(9)(0.206 \mathrm{~g}, 1.19 \mathrm{mmol})$ was added at $0^{\circ} \mathrm{C}$. The reaction mixture was stirred at that temperature overnight, quenched with a sat. ammonium chloride, extracted with ethyl acetate, washed with brine, dried over $\mathrm{MgSO}_{4}$ and concentrated under reduced pressure. The residue was purified by silica gel column chromatography (hexane:ethyl acetate $=4: 1$ ) to give compound $(\mathbf{1 0})(0.189 \mathrm{~g}, 80 \%)$ as a yellow oil : $\mathrm{R}_{f} 0.24$ (hexane:ethyl acetate $\left.=3: 1\right) ;[\alpha]_{\mathrm{D}}^{19.7}$ $+0.1131\left(c=1, \mathrm{CHCl}_{3}\right) ;{ }^{1} \mathrm{H} \mathrm{NMR}\left(400 \mathrm{MHz}, \mathrm{CDCl}_{3}\right) \delta 3.61(\mathrm{~m}, 2 \mathrm{H}), 2.47(\mathrm{~m}, 2 \mathrm{H}), 2.31(\mathrm{br}, 2 \mathrm{H})$, $2.06(\mathrm{~s}, 1 \mathrm{H}), 1.50-1.24(\mathrm{~m}, 12 \mathrm{H}), 0.87(\mathrm{t}, 3 \mathrm{H}, J=6.75) ;{ }^{13} \mathrm{C} \mathrm{NMR}\left(125 \mathrm{MHz}, \mathrm{CDCl}_{3}\right) \delta 81.0,73.6$, 72.5, 71.4, 34.1, 32.4, 30.1, 29.8, 26.2, 24.7, 23.3, 14.7 ; IR (neat) $\vee 3392.1,2924.1,2855.1$, 2362.0, 1653.2, 1457.1 $\mathrm{cm}^{-1}$; HRMS (calcd. 198.30, found 181.2777)

\section{Panaxytriol (1)}


$\mathrm{CuCl}(1.5 \mathrm{mg}), \mathrm{NH}_{2} \mathrm{OH} \cdot \mathrm{HCl}(10 \mathrm{mg})$ and ethyl amine $(0.23 \mathrm{ml})$ were added to a methanol solution of compound (10) $(41 \mathrm{mg}, 0.207 \mathrm{mmol})$ at r.t. A dichloromethane solution of compound (4) $(24.4 \mathrm{mg}, 0.151 \mathrm{mmol})$ was added dropwise to reaction mixture at $0^{\circ} \mathrm{C}$ over 1 hour using syringe pump. For additionally 1 hour, reaction mixture was stirred at $0^{\circ} \mathrm{C}$. Reaction mixture was quenched by water, extracted with dichloromethane, washed with brine, dried over $\mathrm{MgSO}_{4}$ and concentrated under reduced pressure. The residue was purified by silica gel column chromatography (hexane:ethyl acetate $=2: 1)$ to give panaxytriol $(\mathbf{1})(26.6 \mathrm{mg}, 63 \%$ isolated) and compound (10) (12.4mg) : $\mathrm{R}_{f} 0.13$ (hexane:ethyl acetate $\left.=2: 1\right) ;[\alpha]_{\mathrm{D}}{ }^{25}-21.8\left(c=0.8, \mathrm{CHCl}_{3}\right) ;{ }^{1} \mathrm{H}$ NMR (400MHz, $\left.\mathrm{CDCl}_{3}\right) \delta 5.94$ (ddd, 1H, J=17.0, 10.1, 5.35), 5.47 (ddd, 1H, J=17.0, 1.31, 1.21), 5.25 (ddd, $1 \mathrm{H}, J=10.4,1.25,1.15), 4.92(\mathrm{~d}, 1 \mathrm{H}, J=5.35), 3.62(\mathrm{~m}, 2 \mathrm{H}), 2.58(\mathrm{~d}, 2 \mathrm{H}, J=5.78), 2.11$ (br, 3H), 1.51-1.25 (m, 12H), $0.88(\mathrm{t}, 3 \mathrm{H}, J=6.73) ;{ }^{13} \mathrm{C} \mathrm{NMR}\left(125 \mathrm{MHz}, \mathrm{CDCl}_{3}\right) \delta$ 136.4, 117.6, $78.5,75.1,73.5,72.5,71.3,66.9,63.9,34.0,32.2,29.9,29.6,26.0,25.4,23.0,14.5$; IR (neat) $v$ 3524.8, 2930.7, 2854.8, 2360.0, 1457.1 $\mathrm{cm}^{-1}$; HRMS (calcd. 278.39, found 261.1047) 


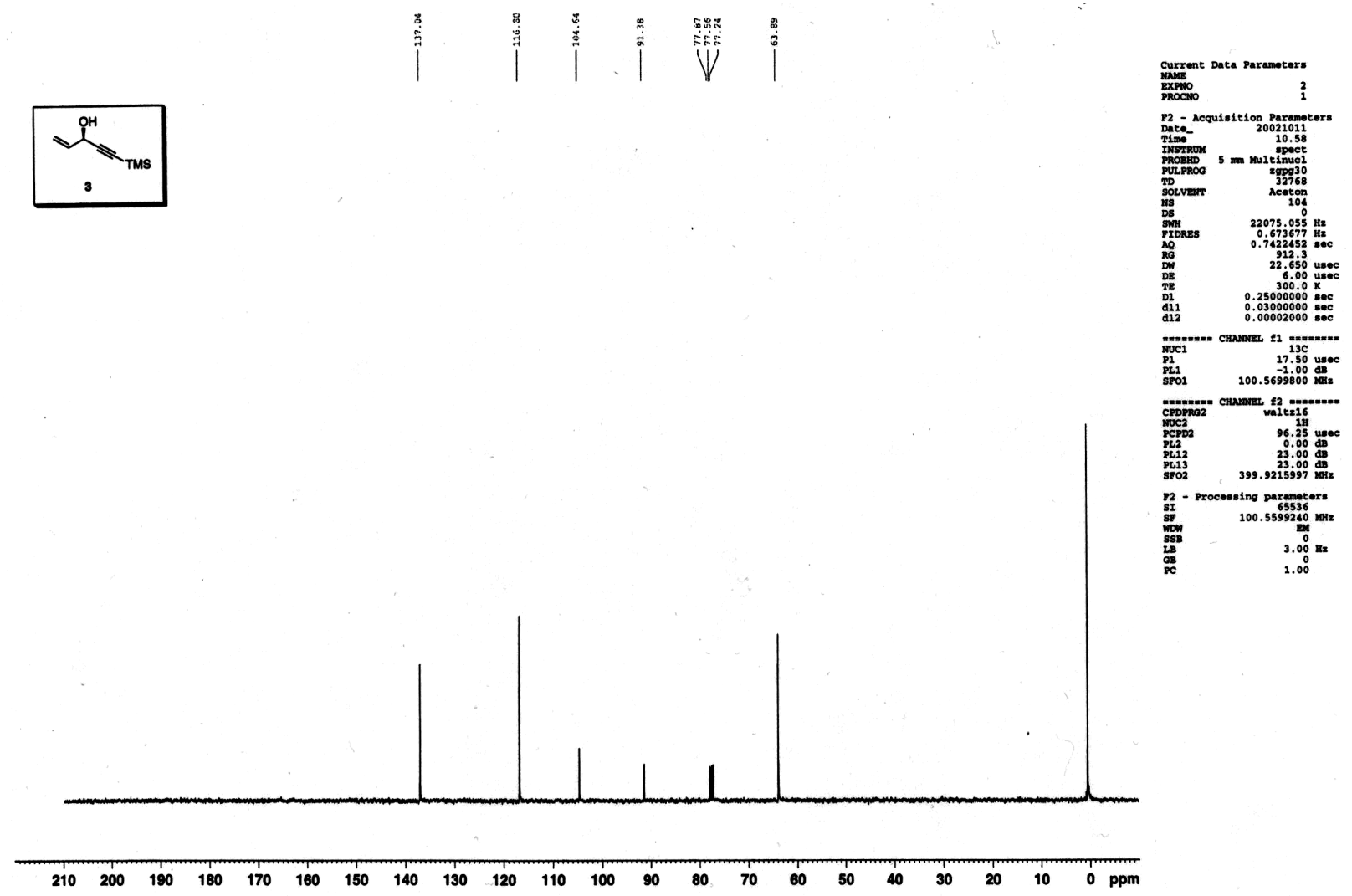

proton $400 \mathrm{Mhz}$

$\overbrace{3}^{\text {OH }}$

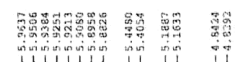

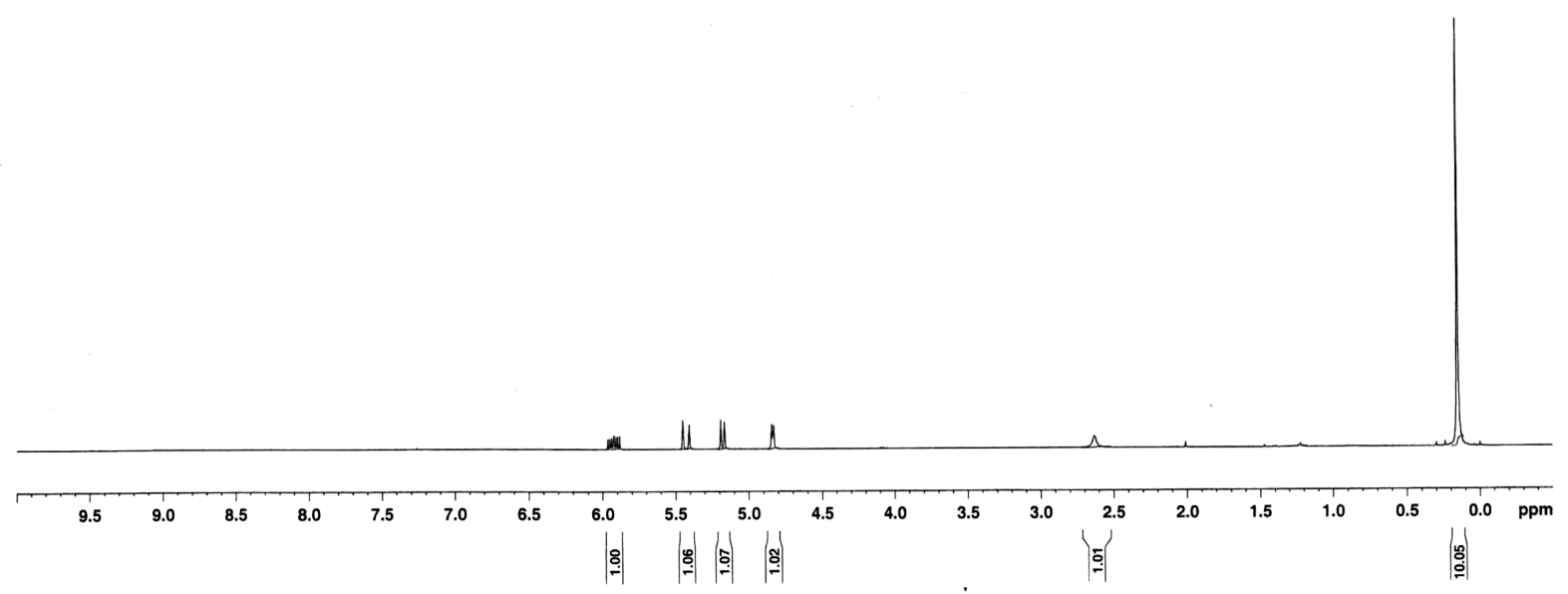



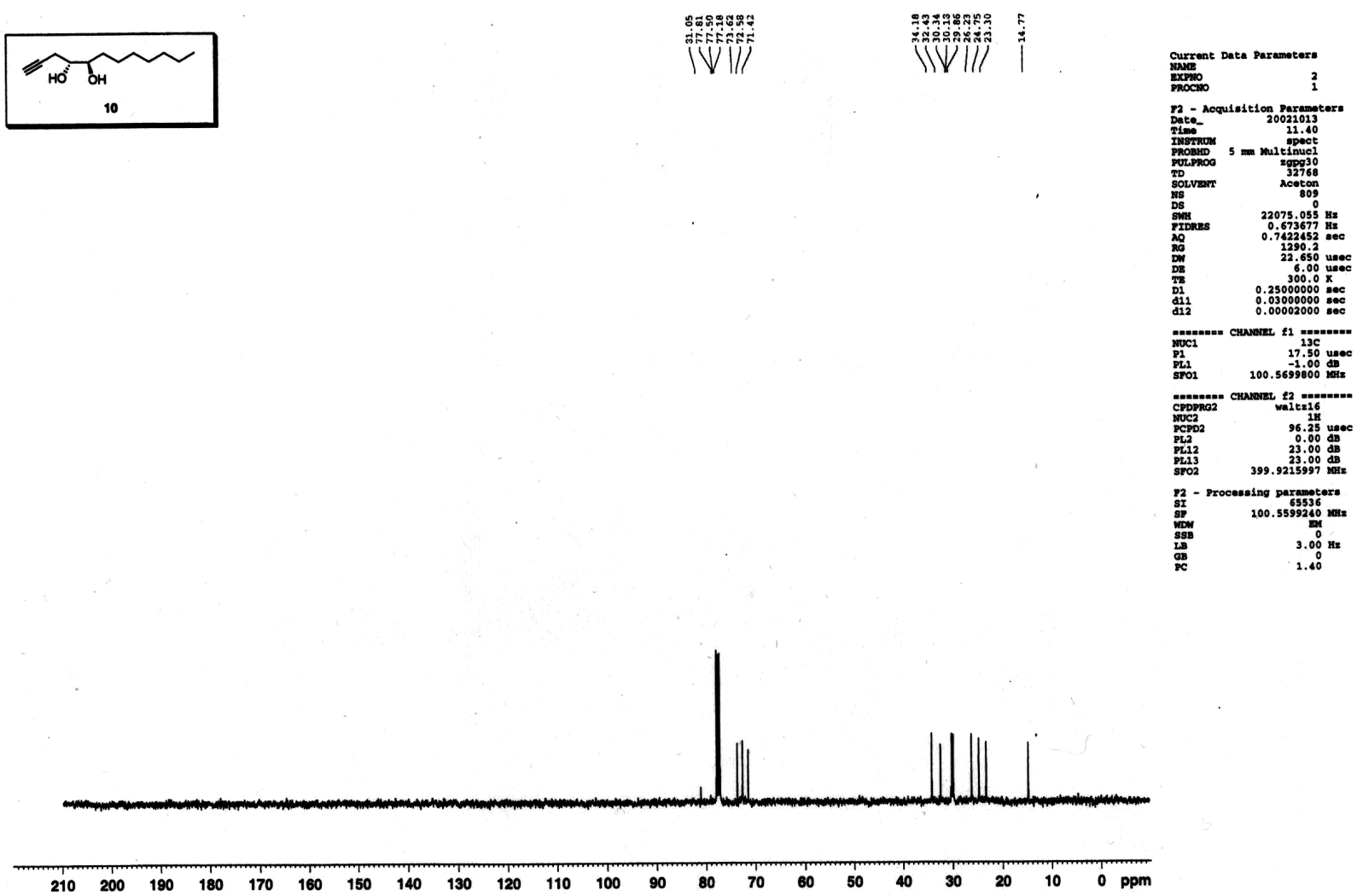

proton $400 \mathrm{Mhz}$
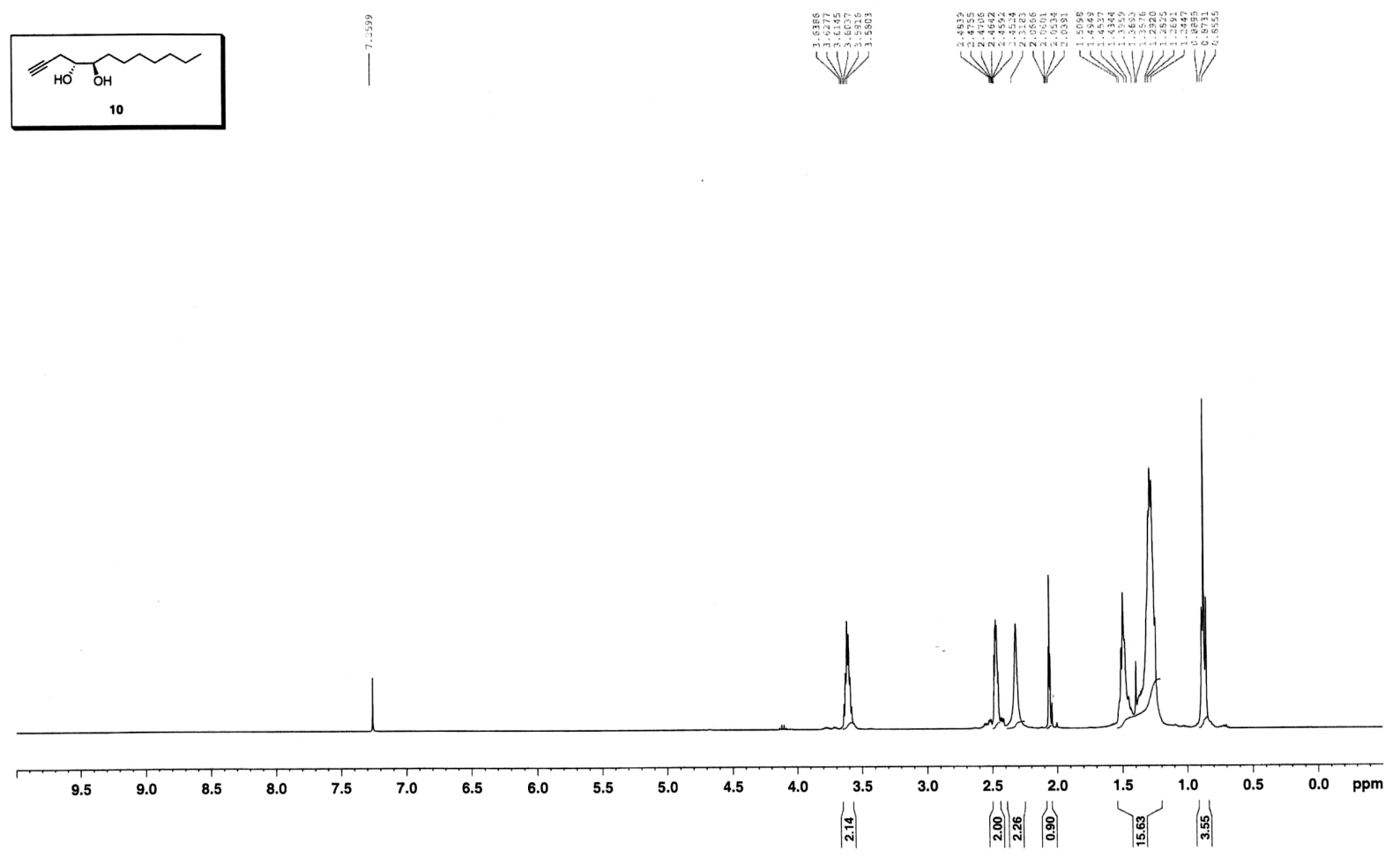

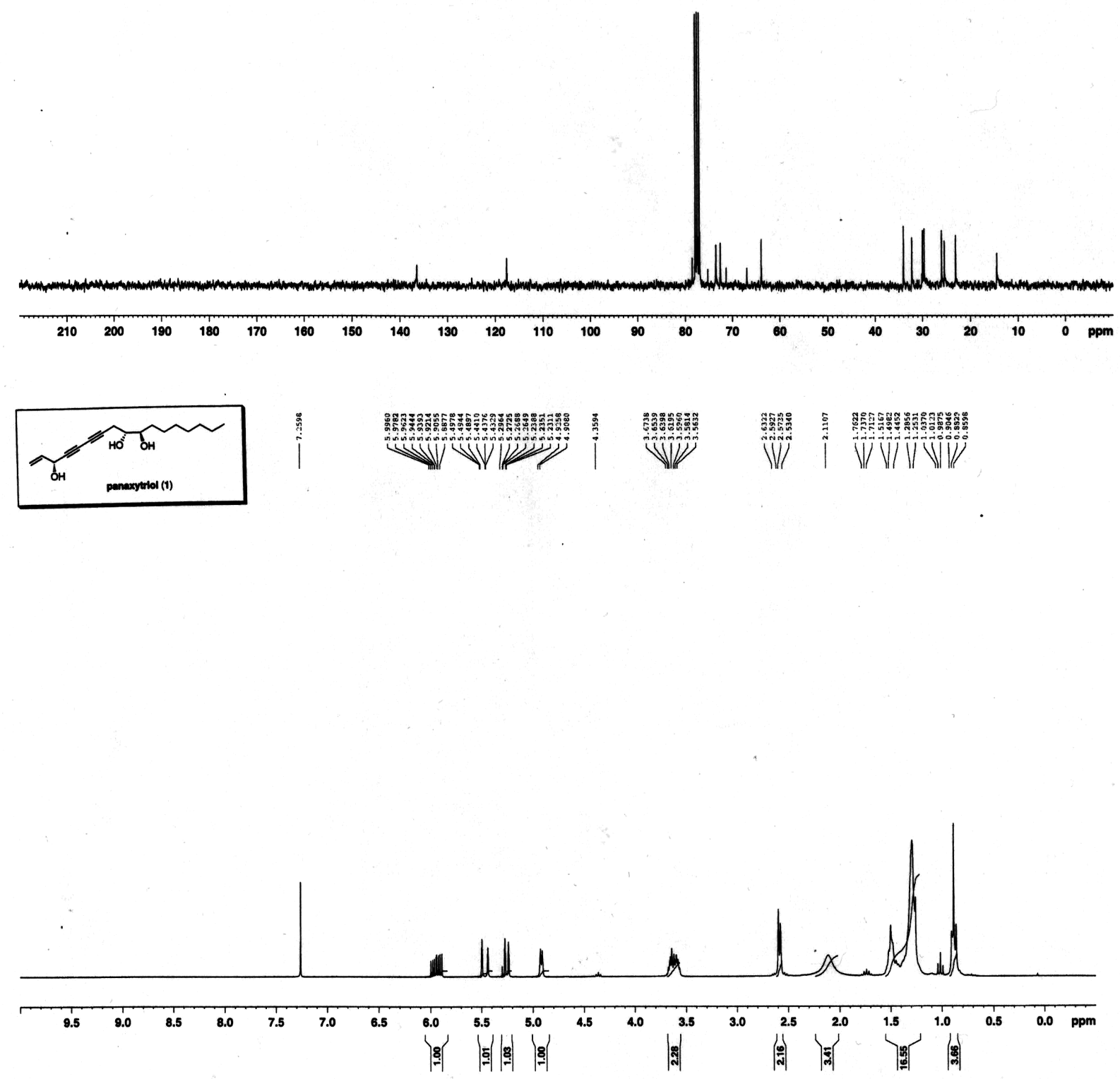